\title{
Analysis of Technical Efficiency of Irrigated Tomato Production in North Gondar Zone of Amhara Regional State, Ethiopia
}

Tigabu Dagnew Koye ( $\nabla$ tigabu567@gmail.com )

University of Gondar https://orcid.org/0000-0002-5328-345X

Abebe Dagnew Koye

University of Gondar

Taye Melese Mekie

University of Gondar

\section{Research}

Keywords: irrigated tomato, SPF, Technical efficiency, yield loss, Cobb-Douglas

Posted Date: January 21st, 2021

DOl: https://doi.org/10.21203/rs.3.rs-150323/v1

License: (c) (i) This work is licensed under a Creative Commons Attribution 4.0 International License.

Read Full License 


\section{Analysis of Technical Efficiency of Irrigated Tomato Production in North Gondar Zone of}

\section{Amhara Regional State, Ethiopia}

\section{Tigabu Dagnew Koye ${ }^{1}$, Abebe Dagnew Koye ${ }^{1}$ and Taye Melese Mekie}

${ }^{1}$ Department of Agricultural Economics, College of Agriculture and Environmental Sciences, University of Gondar, Gondar, Ethiopia; Email: $\underline{\text { tigabu567@gmail.com, }}$ adagnew268@gmail.com, and tayemelese20@gmail.com, respectively

\section{Abstract}

Ethiopia is a country with a total population of more than 110 million, of which about $80 \%$ of the total population is engaged in subsistence farming in rural areas. Although agricultural sector plays a great role in Ethiopian economy, it is characterized by low productivity due to technological and socioeconomic factors. Improving smallholder irrigated tomato production, and productivity, would contribute to enhancing food security and alleviating poverty. Therefore, this study was investigated to fill this gap with the aim of analyzing technical efficiency of irrigated tomato production and its determinant factors in North Gondar Zone, Amhara Regional State, Ethiopia. Primary data were collected from 160 farmers' selected using multistage sampling procedure and analyzed using descriptive statistics, a parametric stochastic frontier production function models. The stochastic frontier and Cobb-Douglas functional form with a one-step approach was employed to analyze efficiency and factors affecting efficiency in irrigated tomato production. The estimated gamma parameters indicated that $80 \%$ of the total variation in tomato output was due to technical inefficiency. The means technical efficiency was found 55\%, and about $6,907.32 \mathrm{~kg}$ of tomato output per hectare was lost due to inefficiency factors implying there is a room for improvement in technical efficiency by $43 \%$ with the present technology. The Stochastic Production Frontier (SPF) result revealed that ODE, DAP and plot size at 1\% and labor at $10 \%$ probability level significantly influencing tomato production. The socio-economic variables that exercised important role for variations in technical efficiency positively were the level of education, $T L U$ and watering in morning, and in contrast age, off farm, watering frequency and training for marketing were found to increase inefficiency significantly among farm households. To get better farmers' efficiency in the production of irrigated tomato a continuous marketing training should be established and strengthening the available farmers training center (FTC) to improve farm productivity. The government and any concerned bodies should be build irrigation canals and other alternatives so as to reduce watering frequency. There should be timely and sufficient supply of DAP to improve farmers' efficiency in production of tomato.

Key words: irrigated tomato, SPF, Technical efficiency, yield loss, Cobb-Douglas 


\section{Background of the study}

Ethiopia is a country with a total population of more than 110 million, of which about $80 \%$ of the total population is engaged in subsistence farming in rural areas (CSA, 2017). Poverty and food insecurity are still prevalent problems in Ethiopia. The causes of food insecurity are various such as extreme weather conditions, environmental degradations, population pressure and policy drawbacks. The economy of the country highly depends on agriculture; a sector that has persistently played a leading part in employment provision, poverty alleviation, food availability, and export earnings. According to National bank of Ethiopia (NBE, 2019) agriculture contributes to more than $33.3 \%$ of the gross domestic product (GDP) and $68 \%$ employment opportunity. Thus, it is the reason why that policy action in Ethiopia is largely based on influencing the dynamism of the agricultural sector.

Although agricultural sector plays a great role in Ethiopian economy, it is characterized by low productivity due to technological and socioeconomic factors. Mostly the farmers with the same resources are producing different per hectare output, because of management inefficiency inputs, limited use of modern agricultural technologies, traditional farming techniques, weak supportive and infrastructural service delivery such as extension, credit, marketing, road and poor agricultural policies (Abate et al., 2019). To transform the situation, the Ethiopian government has design Growth and Transformation Plan (GTP-I) and (GTP-II) in the 5 years (2011-2015) and (20162021) respectively. The center of the plan was enhancing smallholder farmers' agricultural productivity (Davis et al., 2012). According to Asfaw et al. (2010) one of the basic strategies of the Ethiopian government in improving agricultural productivity is to adopt new technologies and use of modern inputs. However, without removing inefficiency in utilization of agricultural inputs, trying to adopt new technology may not bring an expected result.

Ethiopia has a comparative advantage in producing different types of horticultural crops due to its favorable climate, proximity to European and Middle East markets, and relatively cheap labor force (Anonymous, 2012). It produces different types of vegetable crops under rain-fed and irrigation systems (Alemayehu et al., 2010; Ambecha et al., 2012; Anonymous, 2010; Quintin et al., 2013). One crop that is produced is tomato which is rich in vitamins, minerals, and antioxidants (Srinivasan, 2010). It is also rich in essential amino acids, sugars, dietary fibres vitamin B and C, iron, and phosphorus (Ambecha et al., 2012). It is produced at all scales (Anonymous, 2010). Commercial tomato production has expanded along with national agricultural policies and strategies which favor high-value cash crops (Quintin et al., 2013). In spite of the emphasis given to the 
subsector Ethiopian tomato growers are challenged by inconsistent production and low yields (Ambecha et al., 2012). There is a need to examine low productivity of tomato.

One strategy to increase production is expansion of irrigation to promote production of high value crops (Quintin et al., 2013). Maximizing the level of production may be achieved by compromising for high labor cost and incurring other higher factors of production. Efficient utilization and the proper mix of production factors which could improve the current level of production, with a given level of inputs, are not receiving sufficient attention.

Improving smallholder irrigated tomato production, and productivity, would contribute to enhancing food security and alleviating poverty (Ambecha et al., 2012). Agricultural productivity mainly depends on how factors are properly combined and efficiently used. Shanmugam and Venkataramani (2006) and Hassan et al. (2010) reported that efficiency in agricultural production is critical and for the optimum level of production to be achieved, resources must be available and used efficiently. Smallholder farmers, who have scarce agricultural resources, need to improve production efficiency.

According to literature review, there have been various empirical studies conducted to measure technical efficiency in Ethiopia. Some of studies conducted on horticultural crops earlier are: Wassihun et al. (2019) on Analysis of technical efficiency of potato production in Chinga district, Amhara regional state; Abate et al. (2019) on Technical efficiency of smallholder farmers in red pepper production in North Gondar Zone; Weldegiorgis et al. (2018) on Resources use efficiency of irrigated tomato production of smallholder farmers in Hintalo Wajerat district of the South-Eastern Zone of Tigray region in Northern Ethiopia; Dube et al. (2018) on Technical efficiency and profitability of potato production by smallholder farmers in Bale Zone of Ethiopia; Tiruneh et al. (2017) on Technical efficiency determinants of potato production in Welmera district, Oromia. Even though several studies have been conducted on technical efficiency of crops including tomato in Ethiopia, technical efficiency of irrigated tomato farming is still inappreciable and very little is known whether smallholder irrigated tomato producers are efficient or not in North Gondar Zone. Moreover, all those findings might not be applicable to the case of tomato production in North Gondar Zone due to the diverse agro-ecological zone, differences in the product produced, and differences in technology adoption. Moreover, as to the best of the author's knowledge and belief, there were no similar studies undertaken in the study area. Therefore, this study was investigated to fill this gap with the aim of analyzing technical efficiency of irrigated tomato production and its determinant factors in North Gondar Zone, Amhara Regional State, Ethiopia. 


\section{RESEARCH METHDOLOGY}

\section{Description of the Study Area}

The study was conducted in North Gondar Zone, Amhara National Regional State. The Zone is located in the north western part of the country between 11 and 13 North latitude and 35 and 35 East longitudes and $738 \mathrm{Km}$. far from Addis Ababa. The zonal capital is Gondar city and with average elevation of 2133 meters above sea level. The zone is dominated by the agricultural sector, which employs about $90 \%$ of the working force. North Gondar is bordered on the south by Lake Tana, West Gojjam, Agew Awi and the Benishangul-Gumuz Region, on the west by Sudan, on the north by the Tigray Region, on the east by Wag Hemra and on the southeast by South Gondar. The weather conditions of the total area of the Administrative Zone are 50,970 square kms. This zone has a total population of 2,921,470 (2,457,645 rural and 463,825 urban) of which 1,481,726 are men and 1,439,744 are women. The population density is 54.11 persons per square $\mathrm{km}$. The study was conducted in Gondar Zuria, Dembia and Takusa Woreda these Woredas are characterized by Dega and Woiyna Dega and there are mixed farming systems (i.e. livestock rearing and crop productions). The crop production systems are characterized through rain fed and irrigation. According to Zone agriculture department, farmers used irrigation mainly for vegetables production such as onion, tomato, cabbage, pepper, potato etc and very often cereal such as maize and the like. Among these, onion and tomato take the lion share in terms of irrigated land allocated and volume of production Abate et al. (2019).

\section{Sample Size and Sampling Method}

To select sample respondents multi-stage sampling technique was used. In the first stage, out of the total woredas of North Gondar Zone, three Woredas namely Takusa, Dembia and Gondar Zura were selected purposively based on its' tomato production potentials. In the second stage from the selected Woreda, Chemera, Chanikia and Mekonta from Takusa; Abrjeha and Sufankara from Dembia; Sendeba and Ambober from Gondar Zuria; were purposively selected due to the high production potential. Finally, 160 tomato farmers were selected randomly based on proportionally to the number of irrigated tomato producing farmers.

\section{Data Type, Sources and Method of Data Collection}

Both primary and secondary data were employed. Primary data was collected through personal and face-to-face interview using semi-structured and pre-tested interview schedule that was filled up by recruited and trained enumerators under the close supervision of the researchers where as secondary data was obtained from various sources such as reports of bureau of agriculture at different levels, 
NGOs, CSA, Woreda administrative office, previous research findings, Internet and other published and unpublished materials, which was relevant to the study.

Methods of Data Analysis

Descriptive statistics

To get some insight about the characteristics of the sampled farm households, descriptive statistics was used. Descriptive statistical analysis was employed to analyze the survey data using measures of dispersion such as percentage, frequency and measures of central tendency such as mean and standard deviation

\section{Econometrics analysis}

Technical efficiency is the practice of using available resources in the best combination with the aim of maximizing output (Battese and Coelli, 1995). Measuring the technical efficiency of smallholder tomato farmers involved the estimation of a Stochastic Frontier Production Function. The stochastic frontier production function was independently proposed by Aigner et al. (1977) and Meeusen and Van den Broeck (1977). It is defined by:

$Y_{i}=f\left(X_{i} ; \beta\right) \exp \left(V_{i}-\mu_{i}\right) \quad i=1,2,3, \ldots, 160$

Where $\mathrm{Y}_{\mathrm{i}}$, is scalar output of the $i^{\text {th }}$ farm, $\mathrm{Xi}$ is a vector of inputs of the $i^{\text {th }}$ farm, and $\beta$ is a vector of parameters to be estimated. The first error component $v_{i}$ is assumed to be independently and identically distributed and symmetric. This error term represents the random effects, measurement errors, omitted explanatory variables and statistical noise. The second error component, $\mu_{i} \geq 0$ is expected to capture the inefficiency of the irrigated tomato farm and it is assumed to be independently and identically distributed with mean, $\mu$, and variance, $\sigma_{\mu}^{2}$. The technical efficiency for the $i^{\text {th }}$ farm, defined by the ratio of observed production to the corresponding frontier production associated with no technical inefficiency, is expressed by:

$$
\mathrm{TE}_{\mathrm{i}}=\mathrm{f}\left(\mathrm{X}_{\mathrm{i}} ; \beta\right) \exp \left(\mathrm{V}_{\mathrm{i}}-\mu_{\mathrm{i}}\right) / \mathrm{f}\left(\mathrm{X}_{\mathrm{i}} ; \beta\right) \exp \left(\mathrm{v}_{\mathrm{i}}\right)=\exp \left(-\mu_{\mathrm{i}}\right)
$$

A technical efficiency score of 1 indicates a perfectly efficient firm, while lower scores indicate lower efficiencies. The prediction of the technical efficiencies is based on the conditional expectation, given the composed random error $\left(v_{i}-\mu_{i}\right)$, which is to be evaluated at the maximum likelihood estimates of the parameters of the model (Battese and Coelli, 1995).

The estimates for all parameters of the stochastic frontier and inefficiency effect model was estimated in a single stage by using the Maximum Likelihood (ML) method with the help of computer software package FRONTIER 4.1 (Coelli, 1996). 
The stochastic frontier Cobb Douglas production function used for the measurement of technical efficiency is as follows

$$
\ln Y_{i}=\beta_{0}+\beta_{1} X_{1 i}+\beta_{2} X_{2 i}+\beta_{3} X_{3 i}+\beta_{3} X_{3 i}+\beta_{4} X_{4 i}+\beta_{5} X_{5 i}+\beta_{6} X_{6 i}+\varepsilon_{i}
$$

Where: $\ln =$ Natural logarithm; $Y_{i}=$ Tomato output $(\mathrm{kg} / \mathrm{ha}) ; \beta_{0}=$ constant term; $\beta_{\mathrm{i}}=$ regression coefficient of the $i^{\text {th }}$ variable; $\mathrm{X}_{1}=$ Oxen used (oxen-days/ha); $\mathrm{X}_{2}=$ labour used (man-days/ha); $\mathrm{X}_{3}=$ amount of UREA used $(\mathrm{kg} / \mathrm{ha}) ; \mathrm{X}_{4}=$ amount of DAP used $(\mathrm{kg} / \mathrm{ha}) ; \mathrm{X}_{5}=$ amount of tomato seedling used $(\mathrm{kg} / \mathrm{ha}) ; \mathrm{X}_{6}=$ plot size used for tomato production $(\mathrm{ha}) ; \varepsilon_{\mathrm{i}}=$ error term and defined as $\left(\mathrm{v}_{\mathrm{i}}-\mu_{\mathrm{i}}\right)$

$\mathrm{V}_{\mathrm{i}}=$ random effects (measurement errors, omitted explanatory variables) assumed to be independent of $\mu_{\mathrm{i}}$, identically and normally distributed with zero mean and constant variance $\sigma_{v}^{2}$.

$\mu_{\mathrm{i}}=$ non-negative random error variables which are assumed to account for technical inefficiency in tomato farmers.

$\mu_{\mathrm{i}} \mathrm{S}$ is the technical inefficiency effects which are assumed to be independent of $v_{\mathrm{i}}$ such that $\mu_{\mathrm{i}}$ is the non-negative truncation (at zero) of the normal distribution with mean $\mu_{\mathrm{i}}$ and Variance $\delta^{2}$, the inefficiency model is defined by;

$$
\begin{gathered}
\mu_{\mathrm{i}}=\delta_{0}+\delta_{1} \mathrm{Z}_{1 \mathrm{i}}+\delta_{2} \mathrm{Z}_{2 \mathrm{i}}+\delta_{3} \mathrm{Z}_{3 \mathrm{i}}+\delta_{4} \mathrm{Z}_{4 \mathrm{i}}+\delta_{5} \mathrm{Z}_{5 \mathrm{i}}+\delta_{6} \mathrm{Z}_{6 \mathrm{i}}+\delta_{7} \mathrm{Z}_{7 \mathrm{i}}+\delta_{8} \mathrm{Z}_{8 \mathrm{i}}+\delta_{9} \mathrm{Z}_{9 \mathrm{i}}+\delta_{10} \mathrm{Z}_{10 \mathrm{i}} \\
+\delta_{11} \mathrm{Z}_{11 \mathrm{i}}+\delta_{12} \mathrm{Z}_{12}+\delta_{13} \mathrm{Z}_{13 \mathrm{i}}+\delta_{14} \mathrm{Z}_{14 \mathrm{i}}+\delta_{15} \mathrm{Z}_{15 \mathrm{i}}+\delta_{16} \mathrm{Z}_{16 \mathrm{i}}+\delta_{17} \mathrm{Z}_{17 \mathrm{i}}
\end{gathered}
$$

Where: $\mu_{\mathrm{i}}=$ technical inefficiency; $\delta_{\mathrm{i}}=$ inefficiency parameter of the $\mathrm{i}^{\text {th }}$ variable; $\mathrm{Z}_{1}=$ Age (years); $\mathrm{Z}_{2}=$ level of Education (Grades); $\mathrm{Z}_{3}=$ Family size (number); $\mathrm{Z}_{4}=$ total number of livestock holding (TLU); $\mathrm{Z}_{5}=$ off farm income ( 1 for yes, 0 for no); $\mathrm{Z}_{6}=$ Frequency of extension contact (number); $\mathrm{Z}_{7}=$ Irrigation cooperative ( 1 for members, 0 for not members); $\mathrm{Z}_{8}=$ Irrigation water users' association service $\left(1\right.$ for yes, 0 for no); $Z_{9}=$ Fair water distribution service ( 1 for yes, 0 for no); $\mathrm{Z}_{10}=$ Watering at morning ( 1 for preferred, 0 not preferred); $\mathrm{Z}_{11}=$ Watering at noon ( 1 for preferred, 0 not preferred); $\mathrm{Z}_{12}=$ Watering at evening ( 1 for preferred, 0 not preferred); $\mathrm{Z}_{13}=$ Watering at night ( 1 for preferred, 0 not preferred); $\mathrm{Z}_{14}=$ Watering frequency (per 15 days) (number); $\mathrm{Z}_{15}=$ Training on production ( 1 for yes, 0 for no); $\mathrm{Z}_{16}=$ Training on marketing ( 1 for yes, 0 for no), and $\mathrm{Z}_{17}=$ Credit access ( 1 for yes, 0 for no).

\section{RESULT AND DISCUSSION}

\section{Socioeconomic Characteristics of the Sample Households}

The mean age of 41 years implies that the tomato farmers in the study area are within the active working group. The family size for the sample household, on average, was found to be 5.59 with a 
standard deviation of 1.95. Large family size together with small farm land size and the poor production method, it is difficult for the farmer to sustain his/her family. On the other side, large family size is the source of labor for subsistence farming practice in developing country like Ethiopia. The educational level of the household head, on average, was 2 with a standard deviation of 1.25 years of schooling. In terms of TLU, the average livestock holding per household head was found to be 7.21 with standard deviation of 3.89. Regarding to credit users, $65 \%$ and $35 \%$ were non credit and credit users, respectively. This implies that during irrigation movement more than $50 \%$ of farmers were non-credit users. Training enhances the skill of farm management and the technical ability of the farmers. As shown Table 1, about $27.50 \%$ and $7.50 \%$ of the sample households have received training on tomato production and marketing, respectively. In both cases above $30 \%$ of the sample households did not receive training. This indicates that training might have impact on the technical efficiency differentials among the household heads. Compare to watering at noon, evening and night; for the most part of farmers have been preferred watering at the morning $(77.50 \%)$ because soil evaporation is lower early in the morning than later in the day. From the total sample households, $3.75 \%$ of them have reported that they were involved in off farm activities. However, the majority of the sample households (96.25\%) were solely engaged in agricultural activities. Irrigation cooperative in the study areas were established to solve individual problems in group. The survey results showed that about $28.13 \%$ of the sample households were irrigation cooperative members while $71.87 \%$ of them were not irrigation cooperative members. Additionally about $52.50 \%$ of the sample households reported that they established and organized Irrigation water users association service (IWUAS) though it was not properly implemented. Among those service $10 \%$ of them had access to the service of equitable water allocation that is fair water distribution service. In terms of watering frequency $31.88 \%, 50 \%$ and $18.12 \%$ of the sample households irrigate (water) their tomato plot two times, three times and four times per fifteen days, respectively. The result implies that the most frequent watering per fifteen days was three times.

$<$ Table 1>

The average tomato yield was 8,543.12 $\mathrm{kg}$ per ha with a standard deviation of 5,345.88 $\mathrm{kg}$ per ha. Household labor in man hours recorded a mean of 170.47 man-hours. The high number of manhours of household labor could be an indication that most of the tomato farmers rely heavily on labor provided by household members to undertake their activities. This was not surprising because household members are involved in almost all activities of tomato production process. Besides, the average oxen power used for ploughing for tomato production was 20.16 oxen days per ha with a standard deviation of 16.31 oxen days. Moreover, another essential input was seedling, in which the 
average seedling rate was $4.66 \mathrm{~kg}$ per ha with a standard deviation of 5.35 per ha. The mean plot size was 0.37 ha. This probably implies that tomato farmers in the study area are predominantly smallholder farmers. Fertilizer usage in tomato production in the study area can be said to be demanding low both DAP and urea. The continuous cropping on the same pieces of land implied loss of soil fertility and the need for intensive fertilizer usage.

$<$ Table 2>

\section{Estimation of Technical Efficiency}

In this study, individual farmer's technical efficiency in irrigated tomato production was estimated. Prior to the estimation of stochastic technical efficiency frontier, continuous variables selected for estimation were checked for the problem of multicolinearity using Variance Inflation Factor (VIF). Value of VIF more than 10 is usually considered as an indicator of serious multicolinearity (Gujarati, 2006). Regarding the categorical variables, contingency coefficient (CC), which is a chisquare $(\chi 2)$ based measure of association, was employed to check for the presence of multicolinearity. A contingency coefficient value of 0.75 and above (i.e $\geq 0.75$ ) indicates the existence of a stronger relationship between the variables. By looking the contents of the table, it can be concluded that there is no problem of association among the variables as the respective coefficients are very low.

$<$ Table 3>

$<$ Table 4>

$<$ Table 5>

The first null hypothesis tested is, the test for the existence of the inefficiency component of the composed error term of the Stochastic Frontier Model. This is made in order to decide whether the traditional average production function (OLS) best fits the data set as compared to the stochastic frontier model (SFM) selected for this study. If the null hypothesis $\mathrm{H}_{0}: \gamma=\delta_{0}=\delta_{1}=\cdots=\delta_{17}=0$ is accepted against alternative hypothesis $\mathrm{H}_{1}: \gamma=\delta_{0}=\delta_{1}=\cdots=\delta_{17} \neq 0$, then the SFM is identical to OLS specification indicating that there is no inefficiency problem within the tomato output households. This implies that the inefficiency effects do not depend on the household-specific variables and any deviation in observed tomato output from the maximum possible tomato output is because of statistical noise than any other specific factors. The null hypothesis is thus rejected at one degrees of freedom and 5\% significance level. The generalized log-likelihood ratio (LR) statistics, defined by equation $\left\{L R=-2\left[\ln L\left(\mathrm{H}_{0}\right)-\ln L\left(\mathrm{H}_{1}\right)\right]\right\}$ was used to test the validity of the stochastic frontier production function over the ordinary least squares model. LR $=-2 *$ 
$(-155.27+107.25)=96.04$. This value exceeds the critical $x^{2}(5 \%, 1)$ value of 3.84 at $5 \%$ level of significance in Table 6. Thus, the null hypothesis was not accepted indicating that the stochastic frontier production function was an adequate representation of the data, given the corresponding ordinary least squares production function. Hence, stochastic frontier approach best fits the data under consideration.

The second null hypothesis tested was, test for the selection of the appropriate functional form for the data; Cobb-Douglas versus Translog production function the decision to select the functional form depends on the calculated (generalized) likelihood ratio. To select the appropriate specification, both Cobb-Douglas and Translog functional forms were estimated (LR $=-2 *$ $(-107.25+92.99)=28.52)$. The calculated Log likelihood Ratio $(\mathrm{LR})$ is equal to 37.66 and the critical value of $x^{2}$ at 21 degree of freedom and 5\% significance level is 32.67 in Table 6. Thus, the null hypothesis that all coefficients of the interaction terms in Translog specification are equal to zero was accepted. This implies that the Cobb-Douglas functional form adequately represents the data under consideration. Hence, the Cobb-Douglas functional form was used to estimate the technical efficiency of the sample households in the study area.

The third null hypothesis explored is that farm-level technical inefficiencies are not affected by the farm and farmer-specific variables, and/or socio-economic variables included in the inefficiency model i.e. $\mathrm{H}_{0}: \delta_{0}=\delta_{1}=\cdots=\delta_{17}=0$. The inefficiency effect was calculated using the value of the Log-Likelihood function under the stochastic production function model (a model without explanatory variables of inefficiency effects: $\mathrm{H}_{0}$ ) and the full frontier model (a model with explanatory variables that are supposed to determine inefficiency of each: $\{L R=-2[-150.86+$ 107.25 = 87.22]\}. The calculated LR value of 87.22 was greater than the critical value of 27.59 at 17 degree of freedom, this shows that the null hypothesis $\left(\mathrm{H}_{0}\right)$ that explanatory variables are simultaneously equal to zero was not accepted at 5\% significance level. Hence, these variables simultaneously explain the sources of efficiency differences among the sample households.

$<$ Table 6>

The maximum likelihood (ML) estimates of the parameter of the stochastic frontier Cobb-Douglas production function results are presented in Table 7. The standard ordinary least squares (OLS) estimate is also presented for comparison. The sigma $\left(\sigma^{2}=0.37\right)$ is statistically significant at $1 \%$ level of probability, indicating a good fit and correctness of the specified distributional assumption of the composite error term. The technical efficiency analysis of tomato production revealed that there was presence of technical inefficiency effects in tomato production in the study area as 
confirmed by the gamma value of 0.80 that was significance at $1 \%$ level. The gamma $(\gamma)$ (which is the ratio of the variance of the inefficiency component to the total error term) value of 0.80 implies that about $80 \%$ variation in the output of tomato farmers was due to differences in their technical efficiencies (the total variation in output is due to existence of production inefficiency). By implication about $20 \%$ of the variation in output among producers is due to random factors such as unfavorable weather, effect of pest and diseases, errors in data collection and the like. The $(\gamma)$ parameter is very important because it shows the relative magnitude of the inefficiency variance associated with the frontier model which assumes that there is no room for inefficiency in the model. The estimated elasticity of mean output means with respect to oxen, labor, DAP and plot size were $0.01,0.0007,0.002$ and 0.67 , respectively. These coefficients represent percentage change in dependent variable as a result of percentage change in the independent variables.

$<$ Table 7>

Plot size: Elasticity of tomato production to plot size is negative at $1 \%$ level of significance. This implies that a $1 \%$ increase on hectare of plot size will decrease total tomato output by $0.67 \%$. The average Plot size for tomato production is 0.37 ha, this indicates that the allocation of Plot size for tomato production is so low compare to cereal crops (mostly for maize production, teff and others). During the implantation of irrigation the land rent it is not only expensive but also not accessible. Thus, farmers might not be expand their Plot size for tomato production, and not properly and intensively used other inputs like seed, fertilizer (DAP and urea), labor and oxen.

Oxen power-days: The coefficient of oxen power is statistically significant at $1 \%$ significance level and carries an expected positive sign. The positive coefficient shows that an increase in the number of oxen-days in the course of land preparation by $1 \%$ will tend to increase tomato yield by $0.01 \%$; other variables in the model remain constant. This empirical result is supported by the findings of Wassihun et al. (2019) and Abate et al. (2019)

Labor: The coefficient of labor hours is positively related to tomato output at $10 \%$ significance level. Therefore, at $1 \%$ increase in labor hours spent on farms will increase tomato output by $0.0007 \%$. The reason is that during weeding, watering, controlling and collection period farmers need more labor, and especially for land preparation, watering and collection period farmers said that it is a vital time for tomato production. The result agrees with the studies of Weldegiorgis et al. (2018), Abdulkadir (2015), Degefa et al. (2020) and Ahmed et al. (2018).

DAP: The coefficient of DAP was statistically significant at $1 \%$ significance level and carries unexpected negative sign. The result indicated that a $1 \%$ increase in DAP usage would reduce 
tomato yield by $0.002 \%$. The reason is that during the irrigation period farmers might not get enough DAP. During data collection some farmers told that "we have allocated some DAP for irrigation purpose in the last years DAP (that is in winter season)".

A value of $<1$ return to scale indicates tomato farmers were producing in decreasing return to scale; this is diseconomies scale of production, due to managerial inefficiency in using inputs.. The coefficient parameters summation of the partial elasticity 0.66 showed that tomato production in the study areas were operated at decreasing returns to scale. Therefore, an increase in all production inputs by $1 \%$ will increase tomato yield by less than $1 \%$.

$<$ Table 8>

Age: The age of the household influenced inefficiency negatively and statistically significant at 5\% probability level. This implies younger households were relatively more efficient than older farmers. The reason might be younger households had more contacts with extension agent services, plot demonstration and agricultural meetings. This is an important finding which younger households are comparatively more educated than the older farmers. Younger households are more cost efficient than the older ones. Meaning that relatively younger households may produce at a minimum cost. Again difference in the physical effort exerted on tomato production that is the capacity to work energetically may also be a case for more inefficiency level of older household heads. Thus, it can be inferred from this finding that the younger and educated households the more technically efficient. Younger households are better informed about the prices of inputs and outputs due to may be close/better communication with extension agents and experts, access to trainings, use of technologies (cell phone), and have better market information due to well education access. Younger households are eager to use technologies (adopt the new agricultural packages) which was used to search cheap input price and better price for the output. However, there is in contrary finding by Wudineh et al. (2017) suggested that relatively elder farmers have the benefit to manage inputs properly in irrigated potato farmers, this might be due to the nature of the farm practice that needed skills acquired through experience.

Level of Education: The education level of farmers had negative relation with technical inefficiency and significant at $1 \%$ significance level. The result illustrated that farmers with more years of formal schooling were more efficient than their counterparts. As farmers become educated she/he has awareness how to maximize their tomato output with the given limited inputs. Education enhances the acquisition and utilization of information on improved technology by the farmers. Generally, more educated farmers were able to perceive, interpret and respond to new information and adopt improved technologies such as fertilizers, pesticides and planting materials much faster 
than the uneducated farmers. The result agrees with the studies of Usman and Bakari (2013), Jwanya et al. (2014), Ojo et al. (2009)

TLU: The estimated coefficient associated with livestock holding (TLU) is positive and statistically significant at $5 \%$ probability level. Households who have more livestock holding may not have difficulties to purchase inputs like seed, fertilizer and the like and also oxen ownership is among the livestock units considered which help farmers in land preparation and sowing. More livestock ownership also supplies more organic fertilizer to cultivate irrigated tomato. Thus, increase in livestock holding results in an increase in technical efficiency of tomato production.

Off farm income: it is negatively affect tomato production and statistically significant at $1 \%$ probability level. This implied that, farmers who participated in off-farm work were likely to be less efficient in farming as they share their time between farming and other income-generating activities. Productivity suffers when any part of production is neglected. In the study area, farmers more participated in trading like fatting sheep and oxen. The result agrees with the study of Wondimu (2013).

Watering in morning: it is positively affect tomato production and statistically significant at $5 \%$ probability level. The reason is that soil evaporation is lower early in the morning than later in the day. While evaporation is also low at night, fungal diseases may develop, particularly when overhead systems that wet leaves are used. Tomato plants are sensitive to water stress and show high correlation between evaporation and crop yield (Birhanu and Tilahun, 2010). Since wind is usually milder in the morning, less water is wasted during morning irrigations than later in the day, as well.

Watering frequency: it is negatively affect tomato production and statistically significant at $1 \%$ probability level. Due to the shortage of water farmers have been used in shift. As a result, during the production of tomato, the amount of water supplies at the right time in the right amount was not enough. Therefore, tomato yield should be raise in irrigation farming practices mostly depends on timely and adequate application of irrigation water needed for tomato growth, in addition it is vital to determine the growth period when plants are most susceptible to water deficit in order to generate the highest yield per unit area.

Farmers' training related to marketing: it is negatively affects the level of technical efficiency at $10 \%$ statistical level of significance. The reason is that extension agents and other concerned bodies like NGOs mainly focus on training related to production activities rather than marketing. A few days training has been given for the producer related to marketing per year for instance market information related to input and output price, value addition, spreading sales and forward 
contracting. This implies that within a short day training farmers might not be easily understand the benefit of training related to marketing. During data collection farmers said that after production, marketing access or linkage is the main problem, and they should not get continuous training related to marketing, and the district marketing department did not solve their problems by creating market linkages on potential marketing areas like Gondar town and Gende wuha town.

\section{Technical Efficiency Analysis}

The maximum likelihood estimates of the Cobb-Douglas stochastic production function coefficients, which are presented in Table 9, are used to predict the technical efficiencies of the sample individual firms. The results of efficiency analysis revealed that technical efficiency of the smallholder tomato household varied from a minimum of $9 \%$ to a maximum of $93 \%$ with a mean of $55 \%$. In other words, on average smallholder tomato producer households in the study area incur a $45 \%$ loss in output due to technical inefficiency. This implies that on average output can be increased by at least $45 \%$ while utilizing existing resources and technology if inefficiency factors are fully addressed or more precisely, on the average, output can be expanded by as much as $45 \%$ if appropriate measures are taken to improve technical efficiency. The wide variation in technical efficiency estimates is an indication that farmers are still using their resources inefficiently in the production process and there still exists opportunities for improving on their current level of technical efficiency. This result suggests that a few households were not utilizing their production resources efficiently, indicating that they were not obtaining maximum output from their given quantity of inputs.

Another implication of this result is that if the average farmer in the sample were to achieve the technical efficiency (TE) level of the most efficient counterpart, then the average farmer could realize an $40.86 \%$ cost savings [i.e., $(1-(55 / 93)) * 100$ ] in terms of total production costs and maximizing their tomato productivity. Thus, sample households could on average, reduce production cost by $40.86 \%$ by reducing input applications to the technically efficient input mix. A similar calculation for the most technically inefficient household reveals a cost saving of $90.32 \%$ [i. e. , $(1-(9 / 93)) * 100]$. Therefore in short run, it is possible to reduce production cost in tomato production in the study area by an average of $90.32 \%$ by adopting the technology and techniques used by the best performers. Improved efficiency would reduce production costs and increase the gross margin of tomato production and enhance profitability. $<$ Table 9> 
To give a better indication of the distribution of the technical efficiency, a frequency distribution of the predicted technical efficiency is presented in Figure 1. The frequencies of occurrence of the predicted technical efficiency in decile range indicate that the highest number of farmers have technical efficiency between $0.20-0.30$ and $0.80-0.90$, representing about $15 \%$ and $15.63 \%$ of the respondents, respectively. The findings also reveal that there is a huge gap between the least technically efficient and the most technically efficient farmers in the study area.

$<$ Figure 1>

\section{Yield gap due to technical inefficiency}

Yield gap may be defined as the difference between technically full efficient yield and observed yield. Therefore, yield gap is the amount which represents fewer yields due to technical inefficiency. From the Stochastic model defined in equation (2), TE of the $\mathrm{i}^{\text {th }}$ household is estimated to be:

$\mathrm{TE}_{\mathrm{i}}=\frac{\mathrm{Y}_{\mathrm{i}}}{\mathrm{Y}_{\mathrm{i}}^{*}}=\frac{\mathrm{f}\left(\mathrm{X}_{\mathrm{i}} ; \beta\right) \exp \left(\mathrm{v}_{\mathrm{i}}-\mu_{\mathrm{i}}\right)}{\mathrm{f}\left(\mathrm{X}_{\mathrm{i}} ; \beta\right) \exp \left(\mathrm{v}_{\mathrm{i}}\right)}=\exp \left(-\mu_{\mathrm{i}}\right)$

Then, solving for $\mathrm{Y}_{\mathrm{i}}^{*}$, the potential yield of each household is represented as:

$Y_{i}^{*}=\frac{Y_{i}}{T E_{i}}=f\left(X_{i} ; \beta\right) \exp \left(v_{i}\right)$

Where $\mathrm{TE}_{\mathrm{i}}=$ technical efficiency of the $\mathrm{i}^{\text {th }}$ sample household in tomato production $\mathrm{Y}_{\mathrm{i}}^{*}=$ The frontier/potential output of the $\mathrm{i}^{\text {th }}$ sample household in tomato production, and $\mathrm{Y}_{\mathrm{i}}=$ The actual/observed output of the $\mathrm{i}^{\text {th }}$ sample household in tomato production

Based on the equation above and using the values of the actual tomato output obtained and the predicted technical efficiency indices, the potential tomato output was estimated for each sample household in tomato production on hectare basis. The mean result is presented in Table 10 below. It was observed that mean technical inefficiency was $55 \%$ which caused $6,907.32 \mathrm{~kg} / \mathrm{ha}$ yield gap of tomato on the average with mean value of the actual output and the potential output of 8,543.12 $\mathrm{kg} / \mathrm{ha}$ and $15,450.44 \mathrm{~kg} / \mathrm{ha}$, respectively. This shows that sample households in study area were producing on the average $6,907.32 \mathrm{~kg} /$ ha lower tomato output than their potential yield.

$<$ Table 10>

The mean levels of both the actual and potential output during the production year were 8,543.12 $\mathrm{kg} / \mathrm{ha}$ and $15,450.44 \mathrm{~kg} / \mathrm{ha}$, with the standard error of 5,345.88 and 5.956.67, respectively. Figure 2 
illustrates that under the existing practices there is a room to increase tomato yield following the best-practiced farms in the study area.

$<$ Figure 2>

\section{CONCLUSION AND RECOMMENDATIONS}

The traditional average response function is not an adequate representation of production frontier. The significant proportion of the residual variation in the SPF is due to technical inefficiency. This implies that there is a room for improvement through better technical efficiency. The estimated Cobb-Douglas stochastic production frontier shows that there is considerable inefficiency among plots in irrigated tomato production. And this may also be true in other crops. The mean efficiency level of 0.55 indicates that production can be increased by $45 \%$. There is also considerable difference in their efficiency level among plots. Hence if inputs are used to their maximum potential, there will be considerable gain from improvement in technical efficiency. Out of six input variables, four input variables which are DAP, oxen, MDE and plot size statistically significant in the frontier model. Labor and oxen positively affected irrigated tomato production. The positive coefficient of these parameters indicates that an increased use of these inputs will increase the production level to greater extent. DAP and plot size negatively affected an irrigated tomato production. The estimated SPF model together with the inefficiency parameters shows that the level of education, TLU and watering in morning were influenced inefficiency negatively whereas age, off farm, watering frequency and training in marketing were increase the level of technical inefficiency. Based on the findings, the followings recommendations are forwarded: There should be timely and sufficient supply of DAP to improve farmers' efficiency in production of tomato. a continuous marketing training should be established and strengthening of the available farmers training center (FTC) to improve farm productivity. In the study area farmers have been used traditional irrigation system. The government and any concerned bodies should be build irrigation canals and other alternatives so as to reduce watering frequency. Livestock should be encouraged so as to purchase new agricultural technologies like improved seed and fertilizer. Education has a positive effect on technical efficiency. The government should be designed appropriate policy to provide adequate and effective basic educational opportunities for farmers in the study area particularly for integrated adult education.

\section{Abbreviations}

CC: contingency coefficient; C-D: Cobb-Douglas; CSA: Central Statistical Authority; DAP: Di Ammonium Phosphate; Ha: Hectare; Kg: Kilogram; $\mathrm{LH}_{0}$ : $\log$ likelihood ratio of null hypothesis; 
$\mathrm{LH}_{1}$ : $\log$ likelihood ratio of alternative hypothesis; Ln: Natural logarithm; LR: Log likelihood ratio; MDE: Man Day Equivalent; MLE: Maximum likelihood estimator; NBE: National Bank of Ethiopia; NGOs: Non-Governmental Organizations; ODE: Oxen Day Equivalent; OLS: ordinary least square; SPF: stochastic production frontier; TE: Technical efficiency; TLU: Tropical Livestock Unit and VIF: variance inflation factor

\section{Acknowledgements}

We are grateful for the University of Gondar for funding this study. We are also very grateful for North Gondar Agricultural office for giving general information about vegetable production at zone level, and Takusa, Dembiya and Gondar-Zuria Agricultural offices for their cooperation during data collection and providing supplementary secondary data. Last but not least, we thank the respondents of this study for their time and willingness in providing data.

\section{Authors' contributions}

All authors had their own crucial role in the process of completing this study. Study design, data collection, and data analysis, critically review and provide comments on the content and structure of the paper. All authors read and approved the final manuscript.

\section{Funding}

This work was supported by the University of Gondar.

\section{Availability of data and materials}

All authors declare that the data sets used in this manuscript are fully available upon request from the corresponding author.

Competing interests: The authors declare that they have no competing interests.

\section{References}

Abate T M, Dessie AB, Mekie TM, 2019. Technical efficiency of smallholder farmers in red pepper production in North Gondar zone Amhara regional state, Ethiopia. Journal of Economic Structures, 8(1), 18. https://doi.org/10.1186/s4000 8 019-0150-6

Abdulkadir K.O, 2015. An evaluation of the efficiency of onion producing farmers in irrigated agriculture: Empirical evidence from Kobo district, Amhara region, Ethiopia.

Ahmed Kasim Dube, Burhan Ozkan, Amanuel Ayele, Diriba Idahe and Ahmed Aliye, 2018. Technical efficiency and profitability of potato production by smallholder farmers: The case of Dinsho District, Bale Zone of Ethiopia. Journal of Development and Agricultural Economics; Vol. 10(7), pp. 225-235. http://www.academicjournals.org/JDAE 
Aigner, D.J., C.A.K. Lovell and P. Schmidt, 1977. Formulation and estimation of stochastic production function models. Journal of Econometrics, 6(1): 21-37.

Alemayehu, N., D. Hoekstra, K. Berhe, and M. Jaleta, 2010. Irrigated vegetable promotion and expansion: The case of Ada'a District, Oromia Region, Ethiopia: Improving the productivity and market success of Ethiopian farmers: Case study report. International Livestock Research Institute. Addis Ababa, Ethiopia. http://cgspace.cgiar.org/handle/10568/1422

Ambecha, O.G., S. Paul, and B. Emana, 2012. Tomato production in Ethiopia: Constraints and opportunities. Resilience of agricultural systems against crises. Tropentag, 19-21 September 2012, Göttingen-Kassel, Witzenhausen, Germany.

Anonymous, 2010. United Nations food and agriculture organization, Rome http://faostat.fao.org/default.aspx?lange

Anonymous, 2012. Investment opportunity profile for the production of fruits and vegetables in Ethiopia. Ethiopian investment agency, Addis Ababa, Ethiopia

Asfaw S, Shiferaw B, Simtowe F, Muricho G, Abate T and Ferede S, 2010. Socio-economic Assessment of Legume Production, Farmer Technology Choice, Market Linkages, Institutions and Poverty in Rural Ethiopia: Institutions, Markets, Policy and Impacts Research Report No. 3. Field Crops Research, 36(2), 103-111.

Battese, G.E. and T.J. Coelli, 1995. A model of technical inefficiency effect on stochastic frontier production for panel data. Empirical Economics, 20: 325-345.

Birhanu K and K Tilahun, 2010. Fruit Yield and Quality of Drip-Irrigated Tomato under Deficit Irrigation. African Journal of Food Agriculture Nutrition and Development; Vol. 10 No. 2

Coelli T.J., 1996. A guide to FRONTIER version 4.1: A Computer Program for Frontier production and Cost Function Estimation, CEPA Working paper 96/07, University of New England, Armidale

CSA (Central statistical Agency), 2017. Agricultural Sample Survey Report on Area and Production of Crops. Statical Bulletin 586, April, 2018, Addis Ababa.

Davis K, Nkonya E, Kato E, Mekonnen D.A, Odendo M, Miiro R and Nkuba J, 2012. Impact of farmer field schools on agricultural productivity and poverty in East Africa. World development, 40(2), 402-413.

Degefa K, Biru G and Abebe G, 2020. Economic Efficiency of Smallholder Farmers in Tomato Production in BakoTibe District, Oromia Region, Ethiopia. J Agri Sci Food Res 11: 273. doi:10.35248/2593-9173.20.11.273 
Dube AK, Ozkan B, Ayele A, Idahe D and Aliye A, 2018. Technical efficiency and profitability of potato production by smallholder farmers: the case of Dinsho District, Bale Zone of Ethiopia. J Dev Agric Econ 10(July):225-235. https://doi.org/10.5897/JDAE2 017.0890

Gujarati, D. N., 2006. Basic Econometrics. $4^{\text {th }}$ Ed. Tata McGraw-Hill. New Delhi.

Hassan, Y., A.L. Ala, and U.B. Kyiogwom, 2010. Comparative analysis of resource use efficiency in maize production involving local and improved varieties in Zamfara State, Nigeria. $J$. Agric. Environ. 6:17-24.

Jwanya, B.A., Dawang N.C., Mashat I.M. and B.S Gojing, 2104. Technical Efficiency of Rain-Fed Irish Potato Farmers in Plateau State, Nigeria: A Stochastic Frontier Approach. Developing Country Studies Vol.4, No.22, ISSN 2225-0565 (Online). www.iiste.org

Leake Gebresilassie Weldegiorgis, Gidey Kidu Mezgebo, Hareg Gebreegzabher Gebremariam and Zenebe Abraha Kahsay, 2018. Resources Use Efficiency of Irrigated Tomato Production of Small-scale Farmers, International Journal of Vegetable Science, 24:5, 456-465, https://doi.org/10.1080/19315260.2018.1438552

Meeusen, W. and J. Van den Broeck, 1977. Efficiency estimation from Cobb-Douglas production functions with composed error. International Economic Review, 18(2): 435-444.

NBE (National Bank of Ethiopia), 2019. Annual Report for 2018/19. National Bank of Ethiopia, Addis Ababa.

Ojo M.A., Mohammed U. S., Adeniji B. and Ojo A.O., 2009. Profitability and Technical Efficiency in Irrigated Onion Production under Middle Rima Valley Irrigation Project in Goronyo, Sokoto State Nigeria. Continental J. Agricultural Science 3: 7 - 14

Quintin, G., T. Abu, and T. Teddy, 2013. Tomato production in Ethiopia challenged by pest. Report Number 1305, Global Agriculture Information Network, Addis Ababa, Ethiopia.

Srinivasan, R., 2010. Safer tomato production methods: A field guide for soil fertility and pest management, Publication No. 10:740. Asian Vegetable Research and Development Center, Shanhua, Taiwan.

Tiruneh WG, Chindi A and Woldegiorgis G, 2017. Technical efficiency determinants of potato production: a study of rain-fed and irrigated smallholder farmers in Welmera district, Oromia, Ethiopia. J Dev Agric Econ 9(8):217-223. https://doi.org/10.5897/JDAE2 016.0794

Usman, J. and Bakari, U.M, 2013. Productıvity Analysıs of Dry Season Tomato (Lycopersicon Esculentum Mill.) Production in Adamawa State, Nigeria. ARPN; Journal of Science and Technology; VOL. 3, NO. 5, 2225-7217. http://www.ejournalofscience.org 
Wassihun AN, Koye TD, Koye AD, 2019. Analysis of technical efficiency of potato (Solanum tuberosum L.) Production in Chilga District, Amhara national regional state, Ethiopia. Journal of economic structures, 8(1), 34. https://doi.org/10.1186/s40008-019-0166-y

Wondimu Tesfaye, 2013. Determinants of Technical Efficiency in Maize Production: The Case of Smallholder Farmers in Dhidhessa District, Illubabor Zone, Ethiopia. M.Sc. Thesis Presented to School of Graduate Studies of Haramya University.

Wudineh Getahun Tiruneh, Abebe Chindi and Gebremedhin Woldegiorgis, 2017. Technical efficiency determinants of potato production: A study of rain-fed and irrigated smallholder farmers in Welmera district, Oromia, Ethiopia. Journal of Development and Agricultural Economics; Vol. 9(8), pp. 217-223. http://www.academicjournals.org/JDAE 
Figures

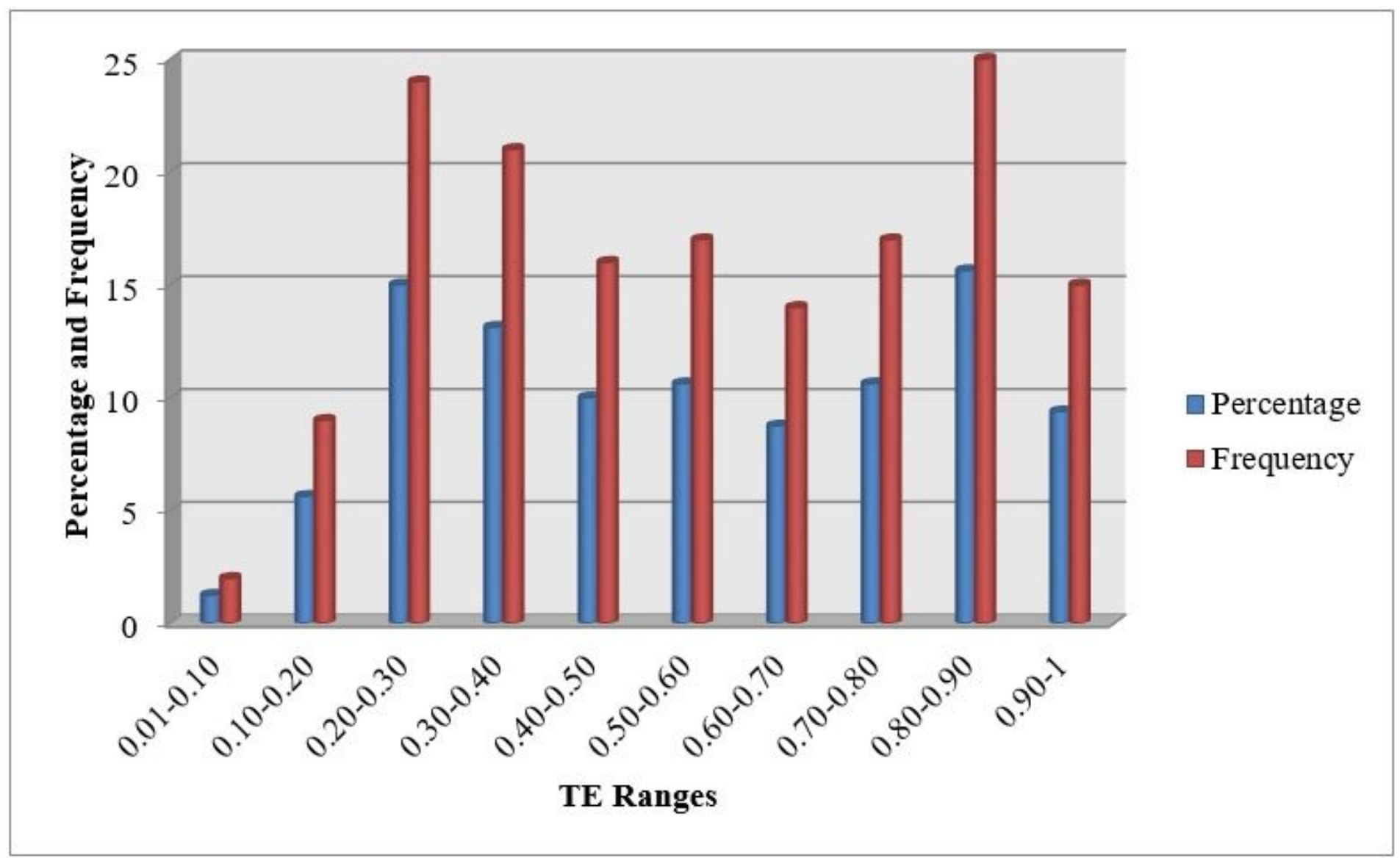

Figure 1

Frequency distribution of technical efficiency. Source: Computed from Field Survey Data, 2015/16 


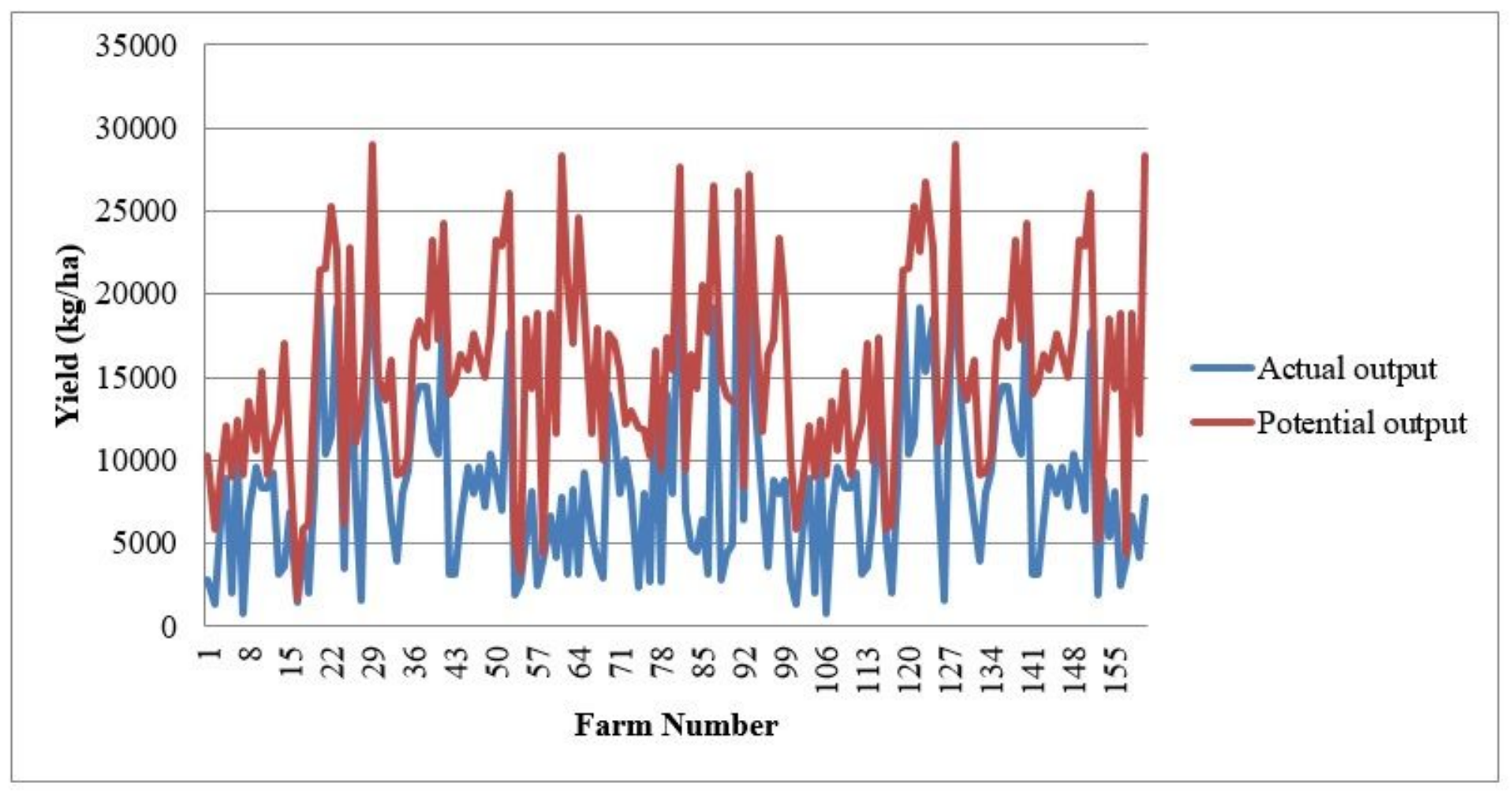

Figure 2

Comparison of the actual and the potential level of yield. Source: Computed from Field Survey Data, 2015/16

\section{Supplementary Files}

This is a list of supplementary files associated with this preprint. Click to download.

- Table.docx 